\title{
STAND EN BETEEKENIS DER COLLECTIEVE ARBEIDSREGELING IN DUITSCHLAND.
}

In een hoogst opmerkelijk opstel der Soziale Praxis van 21 Augustus 1916, blz. 1027, wordt medegedeeld een overzicht der, in Duitschland, einde 1914, tusschen werkgevers en werknemers bestaande arbeidsregelingen (Tarifvereinbarungen). Al hetgeen den socialen vrede bevprderen kan, heeft, als voorbeeld, op zichzelf waarde. In dit opzicht hebben de navolgende, aan bedoeld opstel ontleende, cijfers, onmiskenbaar nut.

Er waren :

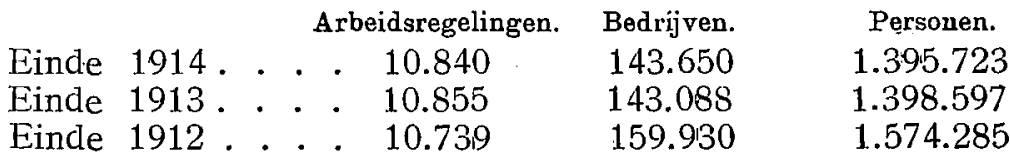

Tweeledige slotsom valt uit deze opgave te trekken.

De eerste op den voorgrond gesteld, is, dat de arbeidsregelingen, zelfs onder den druk van den rampspoedigen oorlog, beproefd en bevestigd zijn. In -menig bedrijf is het bewustzijn ,van gemeenschappelijke bèlan. gen van werkgevers en werknemers intenser geworden en heeft uiting gevonden in vaste regelingen. Verlengd zijn deze voor het bouwbedrijf in al zijn vertakkingen; voor het schilderbedrijf en voor den havenarbeid in de Hansesteden. In talrijke gevallen, werd eene loonverhooging ingewilligd. De lederwerkers, de makers van vliegmachines, de mandemakers traden in nieuwe regelingen. De autoriteiten verleenden hunne bemiddeling tot het effenen der paden, het wegnemen van beletselen, het verwezenlijken van overeenstemming. Van Rijkswege had de bemoeiïng gunstig gevolg en de militaire autoriteiten hebben de, voor hen nieuwe, taak, met geluk en ijver aanvaard. Zoowel bedrijfsgerechten als verzoeningsraden zijn deugdelijk bevonden. Het arbeidsregelingsdenkbeeld: heeft derhalve, in clen oorlog, zijne macht bewezen, al ontbrak het niet aan wederpartijders.

Die macht, en dit is het tweede, niet minder merk- 
waardige punt, wordt nader in het licht gesteld door een sociaal-diemocratischi leider.

Met het oog op de officieele tusschenkomst, zegt hij: „Eerst thans, is de arbeidsregeling tot officieele erken,ning geraakt van hare beteekenis voor de bevorderings "der productie en claarmede voor het gansche volksle, ven. In haar vindli die economische eenheid der natie ",hare uitdrukking." Voorzeker, is allereerst de arlleidsregeling in het leven geroepen, uit het oogpunt van de belangen der arbeidende klasse. Thans echter blijkt zij fundamenteel te zijn, voor hetgeen het volk, als geheel, uitwerken kan, nopens de zekerheid, dat er gearbeid, dat daarin volijverig te werk gegaan wordt, en dat in de verfijnde hoedanigheidsbjewerking ontwikkeling plaats grijpe.

,Deze hooge opvatting, zoo eindigt het opstel, vooral „van die zijde, is in hooge mate verblijdend. De oorlog ",heeft bevestigd, dat de arbeidsregeling, ook in zwaren ,,tijd, waarborgt den rustigen en gestadligen gang van ", die duitsche arbeidlersbevolking; die aan het bedirijf het "meest te stade komt."

Deze les, elders veraanschouwelijkt, behoeft, ook voor ons land, niet te vergeefs verkondigd te zijn. Toen wij de zegening der, thans in ons B. W. opgenomen, codificatie der arbeidsovereenkomst deelachtig werden, lag de collectieve arbeidsregeling nog in de windselen. Het hoogste, waartoe men geraakte, was de afgifte van een naamkaartje, in art. $1637 \mathrm{n}$ lid twee, dat echter het niet onbelangrijk gebrek heeft, de eerste beginselen van ons contractenrecht in het aangezicht te slaan. Indien een of meer werkgevers staan tegenover een of meer vakvereenigingen, en dezen, al waren ' $t$ er honderd, aan weerszijden, gezamenlijlk, iets beraden en beslissen, is dit niet eene c olle cti e ve, maar eene doodeenvout clige en doodgewone arbeidsovereenkomst. ${ }^{1}$ )

Die juridische fout echter heeft, economisch, niet beteekenis. De arbeidsregeling, als werktuig ter bevordiering van den socialen vrede, is van het hoogste gewicht. Als zoodanig kan hare waarde kwalijk worden overschat.

Wat de, daarbij betrokken, personen betreft, vult zij de Zwakhleid, ja onmacht, der individuen aan. Zijibrengt vastheid in het bedrijf en ontneemt de zorg voor den dag van morgen. $Z$ ij predikt die les eener deugdelijke solidariteit tusschen vakgenooten, straks wellicht, want

1) Ik heb dit punt uitgewerkt, in De Collectieve Arbeidsregeling (den Haag 1906). 
goed voorgaan doet goed volgen, tusschen nu, vooralsnog, nog buitenstaanders. Zij' krengt onder woorden, wat niet genoeg gezegd, noch herhlaald.worden kan : een man, een man, een woord, een woord. $Z_{i j}$ verheft het karakterpeil en de beradenheid des arbeidiers, die met zijn werkgever onderhandlelt, als gelijke met gelijke. $\mathrm{Zij}$ openbaart het hoog ethische denkbeeld: in deze onze samenlering, heeft iedier onzer, hoe hoog hij zich diunke, ieder ander, hoe bescheiden hilj arbeide, noodig, zoodat, naar Kant's vermaning, niemand, aan een ander, midd'el, ieder, aan dien ander, doel zijn.

Dit alles is vredeswerk. Wat de arbeidsregeling vermag, in een tijd, waarvoor het den Algooede behaige ons land' te behoedlen, zagen wij zooeven: Ook dit strekke haar tot aanbeveling.

A m sterdam, 1 September 1916.

I. A. L e vy. 